\title{
Implications Transformation Fund Village Regulation About Corona Virus Disease (Covid-19) To New Perspective Social In Village Communities
}

\author{
Nitaria Angkasa ${ }^{1}$ \\ \{nitariapasa@gmail.com ${ }^{1}$ \} \\ Universitas Muhammadiyah Metro, Lampung, Indonesia ${ }^{1}$
}

\begin{abstract}
The priority for the use of village funds is currently undergoing extraordinary changes, based on the provisions instructed by the central government, so that the central government, local governments and village governments take action by changing the regulations and priorities of village funds to help the community. The problems that will be discussed in this article are how the forms of social change that occur in rural communities as a result of the COVID-19 outbreak and its implications, as well as how changes in priority regulations for village funds in helping villagers affected by the COVID-19 outbreak. The method used in this research is empirical norms by conducting literature reviews or literature reviews or social facts. The results showed that the forms of social change that occurred in rural communities, first to the social itself, seco related to the work of rural communities, and the third to the economy of rural communities. The form of regulatory changes in the response to COVID-19 is the Minister of Health Regulation Number 6 of 2020 concerning Amendments to Permendes and PDTT Number 11/2019 concerning Priority for the Use of Village Funds in 2020, this was carried out on the mandate of Perpu Number 1 of 2020 concerning State Financial Policy and Management Financial System Stability Corona Virus Disease 2019 (COVID-19) and / or in the Context of Facing Threats that Endanger the Nation.
\end{abstract}

Keywords: Implications Regulation, Funds Village, COVID-19 and Social Change

\section{Introduction}

With the passing of Law Number 6 of 2014 concerning Villages, villages are given a great opportunity to take care of their own governance, including financial management, and carry out development to improve the welfare and quality of life of rural communities. The implementation of village governance is expected to encourage increased capacity and independence through community participation in utilize resources to achieve community welfare. Implementation is manifested in the form of a government system that regulates longterm development plans, village policies and regulations as well as sources of development financing.[1] Therefore, it is necessary to have a firm and consistent arrangement regarding the budget for village development costs both at the national and regional levels. Regional authority to regulate the proportion of village development budgets is very important as a form of siding with the village community.[2]

The implementation of village autonomy encourages the government and village communities to be more independent in regulating and managing village households, including in this matter regulating and managing the Village Income and Expenditure Budget (APBDesa), Village Original Income (PADesa) as a source of budget revenue or income 
villages play a very important role in village development, and for the implementation of Village autonomy. The Village Revenue and Expenditure Budget (APBDesa) is an integral part of the village household and development policy tools. In supporting the implementation of development in the village, it is necessary to ascertain costs that come from various sources, both government, private and local communities. [3]

The roles and responsibilities accepted by the village have not been balanced with adequate Human Resources (HR) both in terms of quantity and quality. The amount of funds that must be managed by the village government has a high enough risk in its management. Therefore, the government, provincial governments, and district / city governments help empower village communities by assisting in planning, implementing and monitoring village development. Even though the funds owned by a village are very large, if it is not properly regulated in planning and its users, it will result in the funds being wasted or not being able to provide maximum results for the village head.[4] According to Sukasmanto, the process of implementing the village budget is influenced by several factors, namely: transparency, accountability, community participation, effective governance, responses to developing aspirations in the community, and being prepared professionally.

The priority for the use of village funds is currently undergoing extraordinary changes, this is based on the provisions that have been instructed by the central government. This was done because the world is currently experiencing an economic and development crisis caused by the Corona Virus Disease (COVID-19) outbreak. The COVID-19 outbreak not only destroys the world's economy but kills every human being exposed to the virus. This is due to the Corona Virus outbreak which is increasingly increasing the number of victims who are exposed, even those who die in each country. The latest data obtained from Wordometers, 3.1 million cases or more, with 951,030 recovered and 217,094 died. While in Indonesia itself, there are 9,511 people affected by the corona virus, with this data that Indonesia must find the right steps to reduce the number of people affected by the coronavirus. In addition, those who are at the forefront of handling cases of this coronavirus outbreak are the medics, the TNI / Polri and other parties involved.

Thus, the government changed all regulations and rules relating to the use of village funds and village officials made changes to the Village Revenue and Expenditure Budget (APBDesa) which was set in the previous fiscal year to help people who lost their jobs due to the COVID-19 outbreak. The assistance was given directly to the community in the form of direct cash assistance (BLT). The budget comes from the Village Fund which is prioritized to help people who have lost their jobs, because if this is not done by the government, the community will revolt and even many victims who die not because of COVID-19 but from starvation.

Even though this is a form of extraordinary social change felt by the Indonesian people, especially rural communities. The changes range from regulations, priorities, even to the daily lives of village communities who are not allowed to leave the house and must maintain their distance by the government. Based on this, the authors are interested in conducting research in the perspective of social changes that have occurred due to COVID-19 and the form of government responsibility in dealing with this problem by changing the priority regulations for village funds that have been set. The issues that will be discussed in this article are what are the forms of social change that have occurred in rural communities due to the COVID-19 outbreak and its implications, and what are the forms of changes to the priority regulations for village funds in helping rural communities affected by the COVID-19 outbreak. 


\section{Research Methods}

This research is a research using literature review. Literature review or literature research is research that examines, reviews or critically assesses knowledge, ideas, ideas or findings contained in an academic-oriented literature, and formulates and constructs contributions theoretical and methodological for a particular topic. The focus of the literature review is to find various ideas, principles, propositions, theories, or laws that are used to examine and analyze as an effort to answer the research questions formulated.[5] The method of analysis in research with this literature review is descriptive analysis, in which the interpretation of ideas or information / data is carried out regularly and then given a clear explanation so that it can be understood properly.

\section{Discussion}

\subsection{Forms of Social Change Occurring in Village Communities Due to the Outbreak of COVID-19 and its Implications}

In its most concrete sense, social change means that most people are involved in group activities and group relationships that are different from what they have done or what their parents have done before. Society is a complex network of relationship patterns in which all people participate with their respective degrees of relatedness. [6] These relationships change and behavior changes at the same time. Individuals are faced with new situations to which they must respond. These situations reflect certain factors such as technology, new ways of looking for income, changes in place of residence, and new innovations, new ideas, and new values. Thus, social change is a change in how people work, raise their children, educate their children, organize themselves, and seek a deeper meaning in life. Social change can also mean a restructuring in the basic ways in which people in society engage with one another regarding governance, economy, education, religion, family life, recreation, language and other activities.

In modern society, the role of law in social change is more than just theoretical interest. In many areas of social life, such as education, racial relations, housing, transportation, energy use, and environmental protection, law has been recognized as an important instrument of change. In the United States, the law has been used as the primary mechanism for enhancing the political and social position of blacks (blacks). Since the 1960s, courts and Congress have abrogated the racial caste system embedded in law and which has been practiced for generations. The Old Order has been swept away by legislation, including the Civil Rights Act of 1964 and the Voting Rights Act of 1965, followed by billions of dollars in commitments to social welfare programs.[7]

Based on the results of research by conducting interviews, 48 percent of respondents admitted that their social life was disrupted due to the COVID-19 corona virus. The social changes experienced by society today have had a profound impact on social, habitual and economic conditions. Village communities who are accustomed to cooperative life and strong social interactions are trying to find a way out to continue socializing even though there is a physical distancing policy. The use of digital technology is the answer that makes rural communities now begin to depend on their interactions through cyberspace, but not all village communities have technology and able to imply it. This happens because it is impossible for 
someone to be able to be alone continuously. After the COVID-19 corona virus pandemic ended, holding a meeting was a direct reaction to the people's longing to meet. Where many places will be enlivened with gathering activities.

Physical distancing and PSBB policies led to the enactment of WFH. There are many adjustments that people need to make in undergoing WFH. Where discipline is an important value to live a more productive WFH. Meanwhile, there are a number of people who think that WFH makes work more relaxed. That shouldn't be the case, keep doing the habit of getting up early and preparing yourself like working in an office. Meanwhile, for women, it was not easy to undergo WFH. In fact, it is even more tiring than working in an office. Women have to take care of household needs, look after children, as well as do work that is usually done in the office. But on the other hand, entrepreneurs and the government can observe how WFH is a new pattern in carrying out work activities in the future.

Someone's plans for vacations are disturbed and even changed. Tourism is the third sector affected by the COVID-19 corona virus pandemic. Automatically, hospitality has decreased in visitors. Some hotels have eliminated buffets or buffets due to the absence of visitors. This means that spending on restaurant raw materials in hotels is reduced, which has an impact on the lower class economy. So, what about the economic sector? Specifically, this survey does not explain the economic downturn. Rather, it shows the changing style of consumers who rely on digital options. As many as 24 percent of respondents were forced to change their conventional shopping habits online. So that there has been an increase in online shopping activities among the public. Online shopping is not new. However, not all levels of society rely on this option as a shopping activity. The increase in online shopping activities has an impact on economic players who have to prepare digital options suddenly. Not only providing delivery services, but various shopping activities and transactions are also carried out online. Due to urgent factors, making digital services unsatisfactory.[8]

Every crisis there will be a new normal. There will be a change in norms. But there will be an immediate reaction when meeting up. Many companies and governments will understand the impact of WFH. Online shopping will continue and become a new habit, "said Iwan Murty as CEO and Founder of RB Consulting. When the physical distancing and PSBB policies end, it doesn't mean that people will return to their original state. In fact, there are several new habits that emerge and have an impact on life. economy, where the community will maintain some of their online habits, so that business people must finalize their digital options to make them stronger and able to provide satisfying services to consumers.

The changes that have occurred in rural communities due to the outbreak of COVID-19 as mentioned above, as a whole cannot keep up with the development of the times in such a way. Many village people are clueless about making technological developments that are believed to be able to help in their interactions, it turns out that in the village community it cannot be fully utilized. However, this use can be carried out by a young age which can imply the technology. The foregoing is a form of social change that has occurred in rural communities due to the spread of COVID-19.

\subsection{Forms of Changes to Village Fund Priority Regulations in Assisting Village Communities Affected by the COVID-19 Outbreak.}

Law Number 6 of 2014 concerning Villages, villages are given a great opportunity to manage their own governance, including financial management, as well as carry out development to improve the welfare and quality of life of rural communities. [9] The implementation of Law Number 6 concerning Villages is in line with the National Development Program as stated in the 2015-2019 National RPJM, which is "Building 
Indonesia from the periphery by strengthening regions and DESA within the framework of the Republic of Indonesia". As a follow-up, the 2015 APBN-P has allocated Village Funds of \pm IDR 20.776 trillion for 74,093 villages spread across Indonesia, and in the following years it will continue to grow, even reaching more than 1 billion for each village.[10]

In addition to the Village Fund, according to Article 72 of Law Number 6 concerning Villages, villages also manage finances derived from Village Original Income and other Transfer Income in the form of Village Fund Allocation (ADD); Share of Regency / City Taxes and Levies; and Financial Assistance from Provincial / Regency / City APBD.[11] In addition, the village government is expected to be more independent in managing the government and its various natural resources, including financial management and village property.[12] The village has so big a role, of course, accompanied by a big responsibility. Therefore, the village government must be able to apply the principles of transparency and accountability in light of village financial management.

The large amount of funds provided to the village, the various amounts of reporting and the existence of critical points in village financial management, of course, also demands a great deal of responsibility by the Village Government Officials.[13] Therefore the Village Government must be able to apply the principle of accountability in the management of village finances, where all the end of the activities of the village administration must be accountable to the village community in accordance with the provisions so that good village governance can be realized (Good Village Governance).[14] To be able to apply the principle of accountability, various supporting resources and facilities are needed, including competent human resources and adequate and reliable information technology support. However, seen from the inadequate condition of the Village Human Resources, many parties are concerned about the implementation of this Village Law. There are risks that must be anticipated so that what is feared does not occur.

Another obstacle is that the village does not yet have procedures and support for facilities and infrastructure in managing its finances, and the community is not yet critical of managing the village income and expenditure budget.[15] The amount of funds that must be managed should not be a disaster, especially for village government officials. The phenomenon of regional officials being caught in legal cases should not be repeated on the village government scale.[16] Village Government officials and the Village Consultative Body (BPD) must have an understanding of laws and regulations and other provisions, and have the ability to carry out accounting and / or bookkeeping. Therefore, as mandated in Law Number 6 concerning Villages, the Government in this case the Ministry of Home Affairs, the Ministry of Finance, the Ministry of Villages for Disadvantaged Areas and Transmigration, the Provincial Government, Regency / City and District Governments are expected to be more effective in their respective roles in conduct supervision and guidance in managing village finances.[17]

However, this has changed with the policy issued by the Ministry of Villages, Development of Disadvantaged Areas and Transmigration (Kemendes PDTT) changing the priority of using village funds in the midst of the COVID-19 pandemic. Previously, more village funds were provided for two major activities, village development and community empowerment, but now this has changed to address the impact of Covid-19 in villages. Through direct cash assistance (BLT) provided to village communities affected by COVID19. However, this BLT is not something that will fill the empty space of existing assistance, starting from the family hope program (PKH), non-cash food assistance (BPNT), and the preemployment card program.

The policies carried out by the Ministry of PDTT are in accordance with the mandate of Perpu Number 1 of 2020 concerning State Financial Policy and Financial System Stability for 
Handling the 2019 Corona Virus Disease (COVID-19) Pandemic and / or in the Context of Facing Threats that Endanger the National Economy and / or System Stability Finance and Presidential Regulation Number 54 of 2020 concerning Posture Changes and Details of the State Budget for Fiscal Year 2020 and PMK 35 / PMK.07 / 2020 concerning Management of TKDD FY 2020 in the context of Handling the Covid-19 Pandemic and / or facing a Threat that Endangered the Economy National.

With this mandate, the village government in particular must make changes to the Village Revenue and Expenditure Budget (APBDesa) which was set in the previous budget year. This is in accordance with the Instruction of the Minister of Home Affairs No. 3 of 2020 concerning the Prevention of Corona Virus Disease 2019 (COVID-19) in Villages through APBDes. With this change in regulation, it is certain that the village head and his apparatus must form a legal product as an explanation that will cover these changes, namely in the form of village regulations.

The first allocation of village funds is to make villages responsive to COVID-19 by strengthening the village level in preventing the spread of the COVID-19 virus. With village funds, said Anwar, villages must mitigate so that their residents are not exposed to the virus, in addition to being ready to handle if there are residents who are indicated to be infected with COVID-19. The second priority of village funds is for villages to make village cash labor intensive. This is because the COVID-19 pandemic has made rural people lose their jobs in cities, so they have to return to their villages. This has made the poverty rate in the village increase. The use of the third village fund, Anwar continued, was direct cash assistance for villagers. Anwar explained that the cabinet meeting mandated the high wave of unemployment, it was decided that 30 percent of the village fund allocation was used for direct cash assistance.

This change in the authority of village funds was strengthened by the issuance of Village Ministerial Regulation Number 6 of 2020 concerning amendments to Permendes Number 11 of 2019 concerning priorities for the use of village budgets. In addition, Permendes 6/2020 also accommodates the integration of a Mendes circular letter related to the role of villages in handling COVID-19. This change integrates from a circular issued, namely E-Circular Letter Number 4 of 2020 concerning village cash labor intensive, Circular Number 82020 concerning COVID-19 ladder Villages, and Circular Letter Number 11 of 2020 concerning Direct Cash Assistance for rural communities.

\section{Conclusion}

Based on the description above, the conclusions that the author can give in the article are as follows:

1. The form of social change that is felt by the village community as a result of the COVID19 consists of several things: first on the social itself, which means that village people who usually uphold the value of mutual cooperation and gather with community members, with this COVID-19 can't be done. Second, with regard to jobs, village people who usually work in trade, farming and gardening and so on, currently the community cannot do this. Third, changes to the economy, with the implementation of a lockdown, people cannot carry out activities as usual to get sustenance for the sake of making daily needs available, with the COVID-19 outbreak, people can only accept assistance from the government. 
2. The form of regulatory changes made by the government by changing the priority of using village funds to help the community through Direct Cash Assistance. This is based on Permendes No. 6 of 2020 concerning Amendments to Permendes and PDTT No. 11/2019 concerning Priority Use of Village Funds in 2020. This was carried out under the mandate of Perpu Number 1 of 2020 concerning State Financial Policy and Financial System Stability for Handling the Corona Virus Disease 2019 (COVID-19) Pandemic and / or in the Context of Facing a Dangerous Threat National Economy and / or Financial System Stability and Presidential Regulation Number 54 of 2020 concerning Posture Changes and Details of the State Budget for Fiscal Year 2020 and PMK 35 / PMK.07 / 2020 concerning Management of TKDD FY 2020 in the context of Handling the Covid-19 Pandemic and / or facing threats that endanger the national economy.

\section{References}

[1] M. Sofiyanto, R. M. Mardani, and M. G. Salim, "Pengelolaan Dana Desa Dalam Upaya Meningkatkan Pembangunan Di Desa Banyuates Kecamatan Banyuates Kabupaten Sampang," J. Ris. Manaj., vol. 000, no. November 2016, pp. 124-135, 2017.

[2] L. N. Fahri, R. Yulianti, U. S. Raya, and U. Khoiriah, Siti, Meylina, "Pengaruh Pelaksanaan Kebijakan Dana Desa terhadap Manajemen Keuangan Desa dalam Meningkatkan Efektivitas Program Pembangunan Desa," J. Ilm. Bid. Ilmu Adm. Negara, vol. 66, no. 1, pp. 63-72, 2017.

[3] R. D. Sari and O. I. Novi, "Pengaruh Pendapatan Asli Desa, dan Alokasi Dana Desa Terhadap Belanja Desa dan Kemiskinan,” Univ. Muslim Nusant. Al-Washliyah, vol. 2, no. 2, pp. 1-15, 2018.

[4] M. A. LILI, "Pengelolaan alokasi dana desa dalam upaya meningkatkan pembangunan ekonomi masyarakat di desa magmagan karya kecamatan lumar," Artik. Ilm. Ekon. dan Bisnis Univ. Tanjungpura, vol. 1, no. ekonomi, pp. 5-19, 2018

[5] M. Abdul Kadir, "Hukum Dan Penelitian Hukum.," Bandung PT. Citra Aditya Bakti., vol. 8, no. 1, p. 52, 2015, doi: 10.25041/fiatjustisia.v8no1.283.

[6] M. N. Aziiz, "Faktor-Faktor yang Mempengaruhi Akuntabilitas Dana Desa," J. Akunt. Aktual, vol. 6, no. 2, pp. 334-344, 2019, doi: 10.17977/um004v6i22019p334.

[7] R. M. Moonti and Y. Kadir, "Pencegahan Korupsi Dalam Pengelolaan Dana Desa," J. IUS Kaji. Huk. dan Keadilan, vol. 6, no. 3, p. 430, 2018, doi: 10.29303/ius.v6i3.583.

[8] A. Mustanir and D. Darmiah, "Implementasi Kebijakan Dana Desa Dan Partisipasi Masyarakat Dalam Pembangunan Di Desa Teteaji Kecamatan Tellu Limpoe Kabupaten Sidenreng Rappang," J. Polit. Profetik, vol. 4, no. 2, pp. 225-238, 2016.

[9] K. Shuha, J. Akuntansi, F. Ekonomi, and U. N. Padang, "ANALISIS PENGELOLAAN DANA DESA ( Studi Kasus pada Desa-desa Selingkungan Kecamatan Lubuk Alung Kabupaten Padang Pariaman )," Univ. NEGERI PADANG, 2018.

[10] Y. Jamaluddin, A. Sumaryana, B. Rusli, and R. A. Buchari, "Analisis Dampak Pengelolaan dan Penggunaan Dana Desa terhadap Pembangunan Daerah,” JPPUMA J. Ilmu Pemerintah. dan Sos. Polit. Univ. Medan Area, vol. 6, no. 1, p. 14, 2018, doi: 10.31289/jppuma.v6i1.1520.

[11] Achmad Fauzi, "Tata Kelola Dana Desa dalam Rangka Implementasi Undang-Undang Nomor 6 Tahun 2014 Tentang Desa di Kabupaten Sidoarjo Achmad," JKMP (Jurnal Kebijak. dan Manaj. Publik), vol. 53, no. 9, pp. 1689-1699, 2013, doi: 10.1017/CBO9781107415324.004.

[12] U. Khoiriah, Siti, Meylina, "Analisis Sistem Pengelolaan Dana Desa Berdasarkan,” J. Masal. Huk., vol. 66, no. 1, pp. 20-29, 2017.

[13] F. Karimah, C. Saleh, and I. Wanusmawatie, "Pengelolaan Alokasi Dana Desa Dalam Pemberdayaan Masyarakat," J. Adm. Publik, vol. 2, no. 4, pp. 597-602, 2014.

[14] J. Jumaiyah and W. Wahidullah, "Pembenahan Pengelolaan Keuangan Dana Desa: Studi Kasus Desa Sengonbugel," Media Ris. Akuntansi, Audit. Inf., vol. 19, no. 1, p. 19, 2019, doi: 
10.25105/mraai.v19i1.3307.

[15] M. S. R. Nurhayati, "PENGELOLAAN DANA DESA DALAM PERSPEKTIF HUKUM ISLAM," iqtishaduna J. Ilm. Mhs. Jur. Huk. Ekon. Sayriah, vol. 01, no. 01, pp. 68-80, 2019, doi: 10.1017/CBO9781107415324.004.

[16] P. S. S. Anantha and I. K. Sudiarta, "Pengelolaan dana desa sebagai upaya pembangunan desa di desa pererenan, kecamatan mengwi, kabupaten badung," pp. 1-16, 2017.

[17] F. Sri Wahyuni Nur, "Peningkatan transparansi, akuntabilitas, dan partisipatif melalui pengelolaan alokasi dana desa di desa tellumpanuae kabupaten maros," J. Dedik. Masy., vol. 3, no. 1 , pp. 1-9, 2019. 